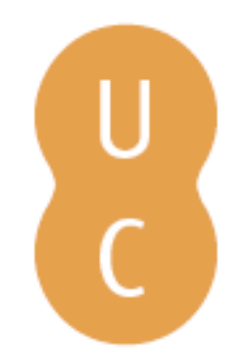

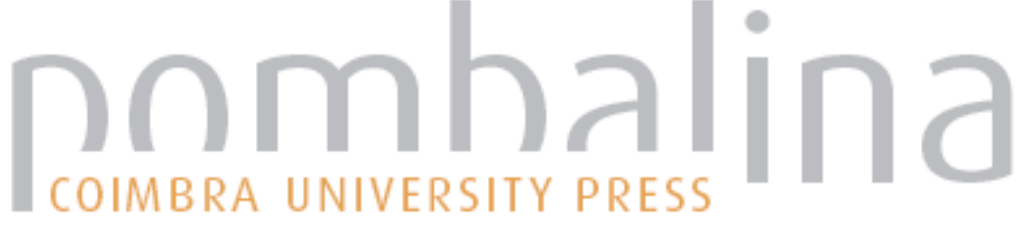

\section{"Carta dos direitos fundamentais da União Europeia": uma visão desde a Antropologia}

\author{
Autor(es): $\quad$ Figueiredo, João
}

Publicado por: Imprensa da Universidade de Coimbra

URL

persistente: URI:http://hdl.handle.net/10316.2/47304

DOI: $\quad$ DOI:https://doi.org/10.14195/978-989-26-1849-4_13

Accessed : $\quad$ 26-Apr-2023 00:33:58

A navegação consulta e descarregamento dos títulos inseridos nas Bibliotecas Digitais UC Digitalis, UC Pombalina e UC Impactum, pressupõem a aceitação plena e sem reservas dos Termos e Condições de Uso destas Bibliotecas Digitais, disponíveis em https://digitalis.uc.pt/pt-pt/termos.

Conforme exposto nos referidos Termos e Condições de Uso, o descarregamento de títulos de acesso restrito requer uma licença válida de autorização devendo o utilizador aceder ao(s) documento(s) a partir de um endereço de IP da instituição detentora da supramencionada licença.

Ao utilizador é apenas permitido o descarregamento para uso pessoal, pelo que o emprego do(s) título(s) descarregado(s) para outro fim, designadamente comercial, carece de autorização do respetivo autor ou editor da obra.

Na medida em que todas as obras da UC Digitalis se encontram protegidas pelo Código do Direito de Autor e Direitos Conexos e demais legislação aplicável, toda a cópia, parcial ou total, deste documento, nos casos em que é legalmente admitida, deverá conter ou fazer-se acompanhar por este aviso.

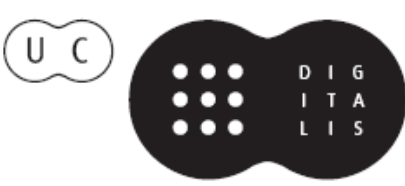


Euro-Atlântico:

Espaço de Diálogos

Isabel Maria Freitas Valente

Iranilson Buriti de Oliveira

(Coord)

\section{VISÕES \\ INTERDISCIPLINARES \\ DA EUROPA \\ E DO MUNDO:}

uma experiência de convergência

disciplinar em homenagem a

Maria Manuela Tavares Ribeiro

Alexandra Aragão

Isabel Maria Freitas Valente

Dulce Lopes

(org.)

Editora da Universidade Federal de Campina Grande

Imprensa da Universidade de Coimbra

2019 


\title{
"CARTA DOS DIREITOS FUNDAMENTAIS DA UNIÃO EUROPEIA", UMA VISÃO DESDE A ANTROPOLOGIA
}

\author{
João Figueiredo
}

Existirão limites cosmológicos para a Carta dos Direitos Fundamentais?

A 15 de março de 2017, os tribunais da Nova Zelândia decidiram conceder ao rio Whanganui personalidade jurídica, bem como todos os deveres e direitos normalmente reservados a um ser humano, dando resposta afirmativa a um pleito local com mais de 140 anos de idade ${ }^{1}$. Venerado pela tribo Maori autodenominada Waitangi enquanto seu ancestral comum, o rio Whanganui serviu imediatamente de exemplo aos juízes Rajeev Sharma e Alok Singh, que propuseram no tribunal indiano da cidade de Nainital, na região dos Himalaias, a atribuição de um estatuto jurídico semelhante aos rios Ganges e Yamuna, sagrados e 'subjectificados' em muitas das culturas e religiões do subcontinente ${ }^{2}$. $\mathrm{O}$ que estes casos testemunham, tendo emanado a partir de dentro de sistemas de 'common law' ao estilo Ocidental, é a crescente abertura ou permeabilidade das ordens jurídicas ocidentalizadas hodiernas a demandas oriundas de sistemas jurídicos ou normativos indígenas, especialmente se estas dizem respeito ao reconhecimento de direitos, deveres e responsabilidades relacionadas com a proteção daquilo que, segundo a mundivisão pós-cartesiana, poderíamos considerar o 'Ambiente' ou a 'Natureza'. Claramente esta tendência acompanha

\footnotetext{
1 Roy, Eleanor, "New Zealand river granted same legal rights as human being", The Guardian, 16 de Março de 2017. Disponível em: https://www.theguardian.com/ world/2017/mar/16/new-zealand-river-granted-same-legal-rights-as-human-being (consultado a 1 de julho de 2019).

2 Safi, Michael, "Ganges andYamuna rivers granted the same legal rights as human beings”, The Guardian, 21 de março de 2017. Disponível em: https://www. theguardian.com/world/2017/mar/21/ganges-and-yamuna-rivers-granted-same-legal-rights-as-human-beings (consultado a 1 de julho de 2019).
} 
o crescente pânico com as alterações climáticas antropogénicas e demais os impactos nefastos dos eventos globais que caracterizam o Antropocénico, pelo que tenderá a afirmar-se.

Havendo chegado aos limites existenciais que uma relação instrumental abusiva e meramente extrativa com a Natureza permite, os tribunais da 'common law' do Sul Global parecem aceder à integração de normas que partem de ontologias diferentes, em que rios e montanhas podem, para todos os efeitos legais, fazer parte das linhagens de grupos sociais. Estará a Carta dos Direitos Fundamentais preparada para acomodar direitos oriundos de ontologias em muito divergentes da matriz greco-romana e judaico-cristã que herdamos do fundo dos séculos? Deverá estar? A par com os Bascos do Norte de Espanha, o único povo indígena europeu que sobrevive ainda no território continental da União Europeia (excluindo, portanto, várias ilhas ao redor do globo e a Guiana Francesa) são os Lapões ou Sami, dividindo-se entre a Suécia, Finlândia, e os territórios dos Estados vizinhos Rússia e Noruega. Nesta situação, como em tantas outras, as regiões ultraperiféricas da União, como a Guiana Francesa, constituem um reservatório de diversidade autóctone aos territórios que não pode ser desprezada.

$\mathrm{O}$ que este fato de existirem povos indígenas Europeus testemunha é que, apara além das conceções de pessoa, ser humano, comunidade e território que hoje informam o Direito comunitário, quer estas provenham de fontes de direito das tradições romano-germânicas ou anglo-americanas, existem outras, nativas ao próprio espaço da União, que oferecem pontos-de-vista preciosos na hora de repensar os limites da atual Carta dos Direitos Fundamentais. Na era do Antropocénico, em que Nova Zelândia e a India assumem institucionalmente a vantagem de aceder afirmativamente a demandas indígenas, como forma de reparar a relação dos povos com o meio natural, seria de todo descabido incluir na Carta dos Direitos Fundamentais direitos relacionados com terras, rios, montanhas e florestas oriundos dos sistemas legais assentes numa cosmologia e ontologia lapónica (por exemplo)? Com certeza que não.

Deveria, contudo, a inclusão na Carta dos Direitos Fundamentais desta novíssima 'família' de Direitos quedar-se por aqueles capazes 
de traçar a sua genealogia aos regimes normativos de povos cuja ancestralidade radica no território do continente Europeu? Como parte da Hospitalidade que a Europa da União presta aos povos que acolhe no seu seio, não deveria ficar assegurada a permeabilidade dos seus charters ou bills of rights a normas assentes em ontologias alheias, mas cuja aplicabilidade no território seja de comprovada utilidade cosmotécnica? Por outras palavras, seria completamente descabido, ainda que para tal não existam antecedentes culturais autóctones, seguir o exemplo indiano e neozelandês e, até enquanto forma de melhor acolher as comunidades maori e hindu na União, declarar que alguns rios que fluem na União possuem também personalidade jurídica, de acordo com o mesmo molde e formalismo que fui seguido nesses países? Não teria a relação dos cidadãos europeus com o meioambiente tudo a ganhar? A aceitação, ainda que formal ou performativa, deste gesto mental, de passar a encarar um rio como 'pessoa' e não mero recurso natural instrumentalizável, produziria com certeza um impacto profundamente positivo na atitude dos demais cidadãos europeus perante a Natureza, ainda que a um nível inconsciente. Em termos práticos, tornaria com certeza as companhias e indivíduos envolvidos na destruição e delapidação do nosso ambiente criminalmente e moralmente responsáveis a um outro nível.

A inclusão, ou não, de direitos oriundos de outras cosmologias ou ontologias revelará a breve trecho se existe ou não um limite interno à expansão da Carta dos Direitos Fundamentais, podendo pelo contrário atestar a sua permeabilidade e vitalidade. 